\title{
Isolation and identification of the pyrethroid insecticide deltamethrin degrading bacteria from insects
}

\author{
Özlem Gür Özdal ${ }^{1 *}$, Ömer Faruk Algur ${ }^{2}$ \\ ${ }^{1}$ Science Faculty, Department of Biology, Ataturk University, Erzurum, Turkey (ORCID: 0000-0003-3460-3638) \\ ${ }^{2}$ Science Faculty, Department of Biology, Ataturk University, Erzurum, Turkey (ORCID: 0000-0001-6447-3454)
}

(İlk Geliş Tarihi 23 Ocak 2020 ve Kabul Tarihi 31 Mart 2020)

(DOI: 10.31590/ejosat.677008)

ATIF/REFERENCE: Gür Özdal, Ö. \& Algur, Ö. F. (2020). Isolation and identification of the pyrethroid insecticide deltamethrin degrading bacteria from insects. Avrupa Bilim ve Teknoloji Dergisi, (18), 905-910.

\begin{abstract}
Many studies have showed that the pesticide residues in the environment increase day by day because of their continuous use. Pesticides can degrade chemically, physically and biologically. Biodegradation is an eco-friendly, inexpensive and highly effective approach compared to other methods. Bacteria are the most commonly used biological agents in biodegradation studies. Widespread use of pyrethroid pesticides such as deltamethrin causes pollution of environment. A total of 14 bacterial isolates were isolated from insects (Poecilimon tauricola, Locusta migratoria, Gryllus bimaculatus and Forficula auricularia) living in pesticide contaminated environments. These bacterial isolates were identified and characterized as Pseudomonas aeruginosa, Stenotrophomonas maltophilia, Bacillus atrophaeus, Acinetobacter lwoffii, Rhodococcus coprophilus, Brevundimonas vesicularis, Pseudomonas syringae, Yersinia frederiksenii, Bacillus licheniformis, Enterobacter intermedius and Serratia marcescens based on biochemical and morphological properties and fatty acid profiles. As a result, these bacterial isolates can be used for the remove of deltamethrin at various environments.
\end{abstract}

Keywords: Bacteria, Biodegradation, Deltamethrin, Isolation

\section{Böceklerden Piretroid İnsektisit Deltametrin Yıkıcı Bakterilerin İzolasyonu ve Tanımlanması}

$\ddot{\text { Ozz }}$

Birçok çalışma, sürekli kullanımları nedeniyle ortamdaki pestisit kalıntılarının her geçen gün arttığını göstermiştir. Pestisitler kimyasal, fiziksel ve biyolojik olarak parçanabilirler. Biyodegradasyon, diğer yöntemlere kıyasla çevre dostu, ucuz ve oldukça etkili bir yaklaşımdır. Biyodegradasyon çalışmalarında bakteriler en sık kullanılan biyolojik ajanlardır. Deltametrin gibi piretroid pestisitlerin yaygın kullanımı çevrenin kirlenmesine neden olmaktadır. Pestisit kontamine ortamlarda yaşayan böceklerden (Poecilimon tauricola, Locusta migratoria, Gryllus bimaculatus ve Forficula auricularia) toplam 14 bakteri izolatı izole edilmiştir. $\mathrm{Bu}$ bakteri izolatları, biyokimyasal ve morfolojik özellikleri ve yağ asidi profillerine dayanarak Pseudomonas aeruginosa, Stenotrophomonas maltophilia, Bacillus atrophaeus, Acinetobacter lwoffii, Rhodococcus coprophilus, Brevundimonas vesicularis, Pseudomonas syringae, Yersinia frederiksenii, Bacillus licheniformis, Enterobacter intermedius ve Serratia marcescens olarak tanımlanmış ve karakterize edilmiştir. Sonuç olarak, bu bakteri izolatları çeşitli ortamlarda deltametrinin parçaalanması için kullanılabilir.

Anahtar Kelimeler: Bakteriler, Biyodegradasyon, Deltametrin, İzolasyon

\footnotetext{
* Sorumlu Yazar: Ataturk University, Department of Biology, Erzurum, Turkey, ORCID: 0000-0003-3460-3638, ozlemgur55@gmail.com
} 


\section{Introduction}

Natural or synthetic pesticides (organochlorine, organophosphate, carbamate, pyrethroids) are widely used to control unwanted pests. Pyrethroids account for about one-fifth of the global agrochemical market. Pyrethroids have potent neurotoxic activity against insects and low toxicity to animals. With the permanent use of pyrethroid worldwide, its residue has become a problem to animals, including humans. Pyrethroid insecticides, e.g., cyphenothrin, fenvalerate, esfenvalerate, deltamethrin, cypermethrin, cyhalothrin, fluvarinate, tralomethrin, cycloprothrin, acrinathrinallethrin, imiprothrin, permethrin and fenpropathrin are used in agriculture, animal health, home, and garden pest control throughout the world (Cycoń and Piotrowska-Seget, 2016; Zhang et al., 2016; Hao et al., 2018).

Pesticides are degraded into simpler and often less toxic chemicals in various ways such as chemical reactions, photodegradation and biodegradation. Biodegradation is an environment friendly, cheap and high efficiency approach compared to other methods. Bacteria and fungi with high enzyme (transferases, isomerases, ligases and hydrolases especially esterases, peroxidases and oxygenases) activity are used in biodegradation studies (Ortiz-Hernández et al., 2013; Ozdal et al., 2017).

Deltamethrin $\left(\mathrm{C}_{22} \mathrm{H}_{19} \mathrm{Br}_{2} \mathrm{NO}_{3}\right)$ is a broad-spectrum insecticide belonging to pyrethroids (Figure 1). Deltamethrin is widely used in agriculture because of its low cost, persistence, stability and low toxicity to mammals. It is used for the control of pests such as mosquitoes, cockroaches, flies, ants and fleas due to effective at very low concentrations (Hao et al., 2018; Lu et al., 2019)

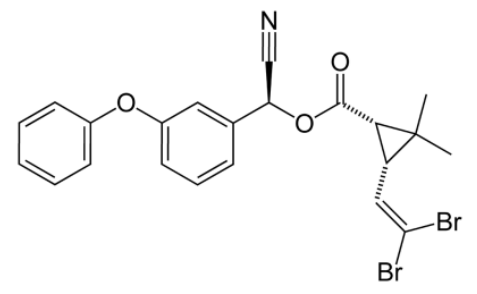

Figure 1. Chemical structure of deltamethrin

Microflora in the digestive tract of insect species is being investigated. The nutrient-rich digestive tract of insects is an appropriate growth environment for these microorganisms. The bacterial flora in the digestive tract of the insect has a very variable and broad enzymatic potential. Insect gut bacterial isolates have been demonstrated to break down many compounds such as pesticide (Ozdal et al., 2016a, b). Insect intestines provide a suitable medium for gene transfer between bacteria. Microorganisms can adapt to new environments by acquiring different features with horizontal gene transfer, conjugative plasmid and simple mutations to different environmental conditions (Pietri et al., 2018; Ramakrishnan et al., 2019). In this context, it is highly possible to isolate pesticide resistant microorganisms from insect intestines.

In many insect groups, resistance to pesticides occurs as a result of the use of pesticides. The intestinal flora of insects, which are observed to be resistant to pesticides, is very rich in bacteria that can be used in the biodegradation of pesticides. The purpose of this study was to isolate the bacteria capable of degrading deltamethrin from different insects.

\section{Materials and Methods}

\subsection{Chemicals}

Deltamethrin and other chemicals used in the study were of analytical purity and were obtained from Sigma and the media were obtained from Merck and Difco.

\subsection{Preparation of media and solutions used in the study}

Carbon-free mineral salt medium (MSM) was used for isolation of deltamethrin degrading bacteria. The medium contained $2.0 \mathrm{~g}$ of $\left(\mathrm{NH}_{4}\right)_{2} \mathrm{SO}_{4}, 0.2 \mathrm{~g}$ of $\mathrm{MgSO}_{4} 7 \mathrm{H}_{2} \mathrm{O}, 0.01 \mathrm{~g}$ of $\mathrm{CaCl}_{2} 2 \mathrm{H}_{2} \mathrm{O}, 0.001 \mathrm{~g}$ of $\mathrm{FeSO}_{4} 7 \mathrm{H}_{2} \mathrm{O}, 1.5 \mathrm{~g}$ of $\mathrm{Na}_{2} \mathrm{H}_{-} \mathrm{PO}_{4} 12 \mathrm{H}_{2} \mathrm{O}$, and $1.5 \mathrm{~g}$ of $\mathrm{KH}_{2} \mathrm{PO}_{4}$ per litre of deionized water (Cycoń et al., 2014). The final $\mathrm{pH}$ value was adjusted to 7.2 . After autoclaving (121 $\left.{ }^{\circ} \mathrm{C}, 15 \mathrm{~min}\right)$ and cooling, the medium was supplemented with $100 \mathrm{mg} / \mathrm{L}$ deltamethrin.

\subsection{Insects used in the study}

The insects belonging to Orthoptera and Dermaptera were collected from different regions during the spring-summer period and species identification Prof. Dr. Orhan Erman. Bacteria that can use deltamethrin as a carbon source were isolated from insects.

\subsection{Isolation of Deltamethrin Degrading Bacteria}

The insect samples were subjected to surface sterilization with $70 \%$ ethyl alcohol for 3 minutes and after alcohol removal with sterile physiological water (SFS), homogenized by crushing in a sterile mortar with SFS (Okay et al., 2013). Serial dilutions of homogenate were prepared and $0.1 \mathrm{~mL}$ of liquid was inoculated to liquid minimal medium containing $100 \mathrm{mg} / \mathrm{L}$ of deltamethrin. After one week, 1 $\mathrm{ml}$ of each culture was re-inoculated into new deltamethrin-MSM medium and further incubated at $30^{\circ} \mathrm{C}$ and $150 \mathrm{rpm}$ for 7 days. This 
subculture was repeated under the same culture conditions, and then an aliquot $(0.2 \mathrm{ml})$ from each culture was applied to solid deltamethrin-MSM for isolation of single colonies. Colonies of different character were isolated by transferring to Tryptic Soy Agar plates and stored on slant agar at $+4{ }^{\circ} \mathrm{C}$.

\subsection{Identification of isolates}

Deltamethrin degrading bacteria were identified using morphological, cultural, biochemical properties (Gram, cell shape, endospores, movement, catalase, oxidase) (Harley and Prescott, 2002) and fatty acid profiles (Kotan et al., 2006).

\section{Results and Discussion}

There is a close relationship between bacteria and other living things. Therefore, insect microflora enables us to find new and biotechnological microorganisms. Serratia marcescens MO-1 isolated from grasshopper (Poecilimon tauricola) has both chitinase activity (Okay et al., 2013) and the ability to produce prodigiosin pigment (Kurbanoglu et al., 2015) which has antimicrobial and anticancer properties. Also, Pseudomonas aeruginosa OG1 isolated from cockroaches (Blatta orientalis) can produce pyocyanin, a pigment of biotechnological importance (Ozdal, 2019). Insects can change their ecological and physiological properties thanks to symbiotic bacteria (Pietri and Liang, 2018). Kikuchi et al., (2012) indicated that bacteria of the genus Burkholderia develop resistance against the fenitrothion (organophosphate pesticide) in the bean bug (Riptortus pedestris). Chlorpyrifos and fipronil resistant strains of diamond back moth (Plutella xylostella) have higher levels of Lactobacillales, Pseudomonadales and Xanthomonadales compared to susceptible insects (Xia et al., 2013). Stenotrophomonas maltophilia OG-2, isolated from the intestine of the cockroach (Blatta orientalis), can degrade both $\alpha$-endosulfan (Ozdal et al., 2017) and synthetic pyrethroid $\alpha$-cypermethrin (Gur et al., 2014).

In this study, insects belonging to Orthoptera and Dermaptera were collected from the areas where insecticides were used (Table 1). As a result of isolations, 14 bacteria were isolated on solid medium containing deltamethrin. Table 1 lists the insect species and isolate groups from which the isolates were obtained.

Table 1 Insect species from which isolates were obtained

\begin{tabular}{ccccc}
\hline $\begin{array}{c}\text { Strain } \\
\text { Group }\end{array}$ & Insect Name & $\begin{array}{c}\text { Place of } \\
\text { collection }\end{array}$ & Family & Order \\
\hline DPT & $\begin{array}{c}\text { Poecilimon tauricola } \\
\text { (Ramme 1951) }\end{array}$ & Erzurum & Tettigoniidae & Orthoptera \\
DLM & $\begin{array}{c}\text { Locusta migratoria } \\
\text { (Linnaeus 1758) }\end{array}$ & İzmir & Acrididae & Orthoptera \\
DGB & $\begin{array}{c}\text { Gryllus bimaculatus } \\
\text { (De Geer 1773) }\end{array}$ & Antalya & Gryllidae & Orthoptera \\
DFA & $\begin{array}{c}\text { Forficula auricularia } \\
\text { (Linnaeus 1758) }\end{array}$ & Samsun & Forficulidae & Dermaptera \\
\hline
\end{tabular}

A total of 14 bacterial isolates were isolated from medium containing deltamethrin based on visible colony differences. Among all these 14 deltamethrin degrading bacterial isolates, 3 were Gram-positive rods and 11 were Gram-negative rods. Total 2 isolates indicated positive results for endospore. All the isolates were catalase positive. Of these isolates, 3 were oxidase positive, 10 were motile and 3 were urease positive (Table 2).

Table 2 Cultural, morphological and biochemical properties of isolates

\begin{tabular}{cccccccc}
\hline Isolate code & Gram & Cell shape & Endospor & Motile & Catalase & Oxidase & Urease \\
\hline DGB1 & - & Rod & - & + & + & + & - \\
DLM1 & + & Rod & - & - & + & - & + \\
DPT1 & + & Rod & + & + & + & - & - \\
DPT2 & - & Rod & - & + & + & - & - \\
DLM2 & - & Rod & - & - & + & - & + \\
DFA1 & + & Rod & + & + & + & - & - \\
DPT3 & - & Rod & - & + & + & - & - \\
DPT4 & - & $\operatorname{Rod}$ & - & + & + & - & - \\
DPT5 & - & $\operatorname{Rod}$ & - & + & + & + & - \\
DLM3 & - & $\operatorname{Rod}$ & - & + & + & - & + \\
DFA2 & - & $\operatorname{Rod}$ & - & + & + & - & - \\
DGB2 & - & $\operatorname{Rod}$ & - & + & + & + & - \\
DGB3 & - & $\operatorname{Rod}$ & - & - & + & - & - \\
DLM4 & - & $\operatorname{Rod}$ & - & - & + & - & - \\
\hline
\end{tabular}


Table 3 Fatty acid profiles of bacteria isolated from insects

\begin{tabular}{|c|c|c|c|c|c|c|c|c|c|c|c|c|c|c|}
\hline \multirow[t]{2}{*}{ Fatty acids } & \multicolumn{14}{|c|}{ Bacteria } \\
\hline & DGB1 & 1 DGB2 & DGB3 & DFA1 & DFA2 & DPT1 & DPT2 & DPT3 & DPT4 & DPT5 & DLM1 & DLM2 & DLM3 & DLM4 \\
\hline 10:0 & & 0.32 & & & 0.62 & & & & 0.30 & 0.26 & & 0.47 & 0.21 & \\
\hline $10: 03 \mathrm{OH}$ & & 3.14 & & & 0.16 & & 3.3 & & 10.12 & 3.18 & & & 2.2 & \\
\hline 12:0 & & 4.3 & 6.37 & & 2.67 & & 4.9 & 5.7 & 1.13 & 4.2 & & 6.4 & 5.09 & 9.8 \\
\hline $12: 02 \mathrm{OH}$ & & 4.9 & & & & & 4.7 & 0.4 & 0.42 & 4.7 & & & 4.29 & \\
\hline 12:0 $3 \mathrm{OH}$ & 2.4 & & 4.92 & & 2.82 & & 4.3 & & 2.3 & & & 0.4 & & 3.2 \\
\hline $13: 0$ iso & & & & & 0.41 & & & & & & & & & \\
\hline $14: 0$ iso & & & & 1.1 & 0.67 & 1.1 & & & & & & & & \\
\hline 14:0 & 3.05 & 0.63 & & & 3.80 & & & 6.3 & 4.7 & 0.58 & 1.9 & 1.7 & 0.65 & \\
\hline 14:0 3ÔH & & & & & & & & 5.57 & & & & & & \\
\hline $15: 0$ iso & & & & 19.1 & 33.67 & 12.47 & & & & & & & & \\
\hline 15:0 Antesio & & & & 40.8 & 12.10 & 50.34 & & & & & & & & \\
\hline 15:0 & 3.38 & & & & & & & 2.1 & & & 2.8 & 0.2 & & \\
\hline $16: 0$ iso & & & & 4.7 & 1.10 & 3.3 & & & & & & & & \\
\hline $16: 1 \mathrm{w} 7 \mathrm{c}$ & & & & & & & & 29.76 & 12.1 & & 6.2 & & & \\
\hline $16: 1 w 9 c$ & & & & & 3.58 & & & & & & & & & \\
\hline $16: 1 \mathrm{w} 11 \mathrm{c}$ & & & & 2.2 & & & & & & & & & & \\
\hline $16: 0$ & 20.7 & 24.8 & 12.5 & 5.1 & 9.05 & 2.74 & 26.4 & 29.99 & 27.3 & 25.2 & 23.2 & 37.2 & 25.66 & 19.44 \\
\hline 16:0 10-methyl & & & & & & & & & & & 14.4 & & & \\
\hline $17: 1 \mathrm{w} 8 \mathrm{c}$ & 2.2 & & 0.93 & & & & & & & & & & & \\
\hline 17:0 cyclo & & 0.85 & & & & & 2.3 & 3.2 & 13.7 & 1 & & 2 & 0.48 & \\
\hline $17: 0$ & 1.1 & 0.13 & & & & & & 1.9 & 0.44 & 0.15 & 1.9 & 0.1 & & \\
\hline $17: 1$ iso $w 10 \mathrm{c}$ & & & & & & & & & & & & & & \\
\hline $17: 0$ iso & & & & 5.9 & 3.11 & 5.7 & 0.3 & & & & & 0.1 & & \\
\hline 17:0 antesio & & & & 15.8 & 0.41 & 16.1 & & & & & & & & \\
\hline 17:0 10-methyl & & & & & & & & & & & 2.4 & & & \\
\hline 17:0 w Cyclo 7-8 & & & & & & & & & & & & 29.1 & & \\
\hline $18: 1 \mathrm{w} 7 \mathrm{c}$ & 52.7 & 42.4 & 5.85 & & 0.84 & & 13.7 & 11.7 & 14.2 & 41.3 & & 2.1 & 44.14 & 3.45 \\
\hline $18: 1 \mathrm{w} 9 \mathrm{c}$ & & & 37.21 & & 1.62 & & & & & & 2.3 & & & 21.67 \\
\hline 18:0 & 0.4 & 0.38 & 2.33 & & 0.22 & & 2.3 & 0.46 & 0.3 & 0.44 & & 1.1 & 0.64 & \\
\hline 18:0 10-methyl & & & & & & & & & & & 6.7 & & & \\
\hline 19:0 & & & & & & & & & & & & 0.7 & & \\
\hline $16: 1 \mathrm{w} 7 \mathrm{c} / 15: 0$ iso & 6.8 & 16.66 & 26.45 & & 10.96 & & 30.6 & & & 17.43 & & 3.6 & 18.29 & 39.6 \\
\hline $\begin{array}{l}2 \mathrm{OH} \\
17: 1 \mathrm{w} 8 \mathrm{c}\end{array}$ & 2.2 & 0.22 & & & & & & & & 0.20 & 0.8 & & & \\
\hline $14: 03 \mathrm{OH} / 16: 1$ iso & & & & & & & & & & & & 9.4 & & \\
\hline
\end{tabular}

According to the results of MIS analysis, fatty acid profiles of the isolates are summarized in Table 3. As a result of MIS analysis, 8 different genera and 13 different species of bacterial isolates were identified. Isolates based on morphological, biochemical and fatty acid data were identified as Acinetobacter lwoffii (DLM4), Pseudomonas aeruginosa (DPT5, DBG2), Stenotrophomonas maltophilia (DFA2), Bacillus licheniformis (DFA1), DLM1), Bacillus atrophaeus (DPT1), Pseudomonas syringae (DPT2), Yersinia frederiksenii (DLM2), Enterobacter intermedius (DPT3), Serratia marcescens (DPT4) and Flavimonas oryzihabitans (DLM3). The genera of the isolated bacteria were mainly identified as Pseudomonas and Bacillus. The highest bacterial diversity was observed in Poecilimon tauricola (5) and Locusta migratoria (4).

Table 4 Deltamethrin degrading microorganisms isolated from different environments

\begin{tabular}{lll}
\hline \multicolumn{1}{c}{ Strain } & \multicolumn{1}{c}{ Source } & \multicolumn{1}{c}{ Reference } \\
\hline $\begin{array}{l}\text { Streptomyces aureus HP-S-01 } \\
\text { Bacillus cereus } \text { Y1 }\end{array}$ & Activated sludge & Chen et al., 2011 \\
$\begin{array}{l}\text { Lysinibacillus fusiformis ZJ6 } \\
\text { Acinetobacter calcoaceticus MCm5 }\end{array}$ & Deltametrin contaninated soil & Zhang et al., 2016 \\
$\begin{array}{l}\text { Brevibacillus parabrevis } \text { FCm9 } \\
\text { Sphingomonas } \text { sp. RCm6 }\end{array}$ & Pyrethroid contaninated soil & Hao et al., 2018 \\
Bacillus megaterium JCm2 & Pyrethroid contaninated soil al., 2015a \\
Rhodococcus sp. JCm5 & & \\
$\begin{array}{l}\text { Ochrobactrum anthropi JCm1 } \\
\text { Pseudomonas aeruginosa JQ-41 }\end{array}$ & Pyrethroid contaninated soil al., 2015b \\
$\begin{array}{l}\text { Serratia marcescens } \text { DeI-1, DeI-2 } \\
\text { Acinetobacter baumannii ZH-14 }\end{array}$ & Deltamethrin treated soil & Song et al., 2015 \\
\hline
\end{tabular}

Many different bacteria have been isolated and characterized with their ability to degradation various pesticides. In previous studies, bacteria capable of degrading deltamethrin were mostly isolated from agricultural areas where intensive pesticides were used. However, the potential of these microorganisms to degrade deltamethrin has been confirmed for some bacteria of the genera Acinetobacter, Bacillus, Brevibacillus, Pseudomonas, Serratia, Rhodococcus (Table 4). Song et al., (2015) studied the deltamethrin biodegradation with Pseudomonas aeruginosa JQ-41 strain isolated from the pyrethroid contaminated soil. In another study, Acinetobacter calcoaceticus MCm5 was used in biodegradation of deltamethrin (Akbar et al., 2015a). Similar bacteria were isolated 
in this study. When Table 4 is analyzed, it is seen that the bacteria used in deltamethrin degradation are generally isolated from soil and sludge. All bacteria obtained from this study were isolated from insect flora. In addition, it has been determined that new species may be effective in deltamethrin biodegradation.

The bacteria isolated in this study can undoubtedly be used in biodegradation studies. As seen in Table 5, different strains of the species isolated in this study have been reported to have been used for the degradation of many different pesticides. It has been determined that insects are important source for the isolation of bacteria that break down pesticides.

Table 5 Comparison of the use of the isolated species in the degradation of different pesticides

\begin{tabular}{|c|c|c|}
\hline Bacteria & Pesticide & References \\
\hline \multirow[t]{2}{*}{ Acinetobacter lwoffii } & Endosulfan & Ozdal et al., 2016b \\
\hline & Atrazine & Yang et al., 2017 \\
\hline \multirow[t]{4}{*}{ Pseudomonas aeruginosa } & Endosulfan & Ozdal et al., 2016b \\
\hline & Fenvalerate & Fulekar, 2009 \\
\hline & $\begin{array}{l}\text { Acephate, dimethoate, parathion, } \\
\text { chlorpyrifos, malathion }\end{array}$ & Ramu and Seetharaman, 2014 \\
\hline & chlorpyrifos and dichlorvos & Gaonkar et al., 2019 \\
\hline \multirow[t]{2}{*}{ Stenotrophomonas maltophilia } & $\alpha$-endosulfan, $\alpha$-cypermethrin & Gur et al., 2014; Ozdal et al., 2017 \\
\hline & Diazinon & Pourbabaee et al., 2018 \\
\hline \multirow{2}{*}{ Bacillus licheniformis } & Fenvalerate & Tang et al., 2018 \\
\hline & $\beta$-cyclodextrin, $\beta$-cypermethrin & Zhao et al., 2015 \\
\hline Bacillus atrophaeus & $\alpha$-Endosulfan & Ozdal et al., 2016b \\
\hline Pseudomonas syringae & & \\
\hline $\begin{array}{l}\text { Yersinia frederiksenii } \\
\text { Enterobacter intermedius }\end{array}$ & Permethrin & Lee et al., 2004 \\
\hline Serratia marcescens & DDT & Neerja, Grewal et al., 2016 \\
\hline Flavimonas oryzihabitans & DDT & Barragan-Huerta et al., 2007 \\
\hline
\end{tabular}

\section{Conlusion}

Strains of Pseudomonas aeruginosa, Stenotrophomonas maltophilia, Bacillus atrophaeus, Acinetobacter lwoffii, Rhodococcus coprophilus, Brevundimonas vesicularis, Pseudomonas syringae, Yersinia frederiksenii, Bacillus licheniformis, Enterobacter intermedius and Serratia marcescens, able to use deltamethrin as the only carbon source, were isolated from Poecilimon tauricola, Locusta migratoria, Gryllus bimaculatus and Forficula auricularia. Pesticide resistant insect microbiota has been shown to be a rich source for isolation of microbes that can degradation pesticides and a promising tool for biotechnological discovery in bioemediation programs. In order to find new biocatalysts in the degradation of pesticides, isolation can be made from insects that can live in pesticide environments. As a result, it can be said that isolated deltamethrin degrading microorganisms can be used in the treatment studies in the dirty areas of this insecticide. However, optimization studies are also needed to make biodegradation highly efficient and feasible.

\section{References}

Akbar, S., Sultan, S., \& Kertesz, M. (2015a). Determination of cypermethrin degradation potential of soil bacteria along with plant growth-promoting characteristics. Current Microbiology, 70(1), 75-84.

Akbar, S., Sultan, S., \& Kertesz, M. (2015b). Bacterial community analysis of cypermethrin enrichment cultures and bioremediation of cypermethrin contaminated soils. Journal of Basic Microbiology, 55(7), 819-829.

Barragan-Huerta, B. E., Costa-Pérez, C., Peralta-Cruz, J., Barrera-Cortés, J., Esparza-García, F., \& Rodríguez-Vázquez, R. (2007). Biodegradation of organochlorine pesticides by bacteria grown in microniches of the porous structure of green bean coffee. International Biodeterioration \& Biodegradation, 59(3), 239-244.

Chen, S., Lai, K., Li, Y., Hu, M., Zhang, Y., \& Zeng, Y. (2011). Biodegradation of deltamethrin and its hydrolysis product 3phenoxybenzaldehyde by a newly isolated Streptomyces aureus strain HP-S-01. Applied Microbiology and Biotechnology, 90(4), 1471-1483.

Cycoń, M., \& Piotrowska-Seget, Z. (2016). Pyrethroid-degrading microorganisms and their potential for the bioremediation of contaminated soils: a review. Frontiers in Microbiology, 7, 1463.

Cycoń, M., Żmijowska, A., \& Piotrowska-Seget, Z. (2014). Enhancement of deltamethrin degradation by soil bioaugmentation with two different strains of Serratia marcescens. International Journal of Environmental Science and Technology, 11(5), $1305-1316$.

Fulekar, M. H. (2009). Bioremediation of fenvalerate by Pseudomonas aeruginosa in a scale up bioreactor. Romanian Biotechnological Letters, 14, 4900-4905.

Gaonkar, O., Nambi, I. M., \& Suresh Kumar, G. (2019). Biodegradation kinetics of dichlorvos and chlorpyrifos by enriched bacterial cultures from an agricultural soil. Bioremediation Journal, 23(4), 259-276.

Gür, Ö., Özdal, M., \& Algur, Ö. F. (2014). Biodegradation of the synthetic pyrethroid insecticide $\alpha$-cypermethrin by Stenotrophomonas maltophilia OG2. Turkish Journal of Biology, 38(5), 684-689.

Hao, X., Zhang, X., Duan, B., Huo, S., Lin, W., Xia, X., \& Liu, K. (2018). Screening and genome sequencing of deltamethrindegrading bacterium ZJ6. Current Microbiology, 75(11), 1468-1476.

Harley, J. P., \& Prescott L.M. 2002. Laboratory Exercises in Microbiology. McGraw-Hill Pub. 5th edition.

e-ISSN: 2148-2683 
Kikuchi, Y., Hayatsu, M., Hosokawa, T., Nagayama, A., Tago, K., \& Fukatsu, T. (2012). Symbiont-mediated insecticide resistance. Proceedings of the National Academy of Sciences, 109(22), 8618-8622.

Kotan, R., Sahin, F., \& Ala, A. (2006). Identification and pathogenicity of bacteria isolated from pome fruit trees in the Eastern Anatolia region of Turkey. Journal of Plant Diseases and Protection, 8-13.

Kurbanoglu, E. B., Ozdal, M., Ozdal, O. G., \& Algur, O. F. (2015). Enhanced production of prodigiosin by Serratia marcescens MO-1 using ram horn peptone. Brazilian Journal of Microbiology, 46(2), 631-637.

Lee, S., Gan, J., Kim, J. S., Kabashima, J. N., \& Crowley, D. E. (2004). Microbial transformation of pyrethroid insecticides in aqueous and sediment phases. Environmental Toxicology and Chemistry: An International Journal, 23(1), 1-6.

Lu, Q., Sun, Y., Ares, I., Anadón, A., Martínez, M., Martínez-Larrañaga, M. R., Yuan, X., Wang, M.A., \& Martínez, M. A. (2019). Deltamethrin toxicity: A review of oxidative stress and metabolism. Environmental Research, 170, $260-281$.

Neerja, Grewal, J., Bhattacharya, A., Kumar, S., Singh, D. K., \& Khare, S. K. (2016). Biodegradation of 1, 1, 1-trichloro-2, 2-bis (4chlorophenyl) ethane (DDT) by using Serratia marcescens NCIM 2919. Journal of Environmental Science and Health, Part $B, 51(12), 809-816$.

Okay, S., Özdal, M., \& Kurbanoğlu, E. B. (2013). Characterization, antifungal activity, and cell immobilization of a chitinase from Serratia marcescens MO-1. Turkish Journal of Biology, 37(6), 639-644.

Ortiz-Hernández, M. L., Sánchez-Salinas, E., Dantán-González, E., \& Castrejón-Godínez, M. L. (2013). Pesticide biodegradation: mechanisms, genetics and strategies to enhance the process. Biodegradation-Life of Science, 251-287.

Ozdal, M., Ozdal, O. G., \& Algur, O. F. (2016a). Isolation and characterization of $\alpha$-endosulfan degrading bacteria from the microflora of cockroaches. Polish Journal of Microbiology, 65(1), 63-68.

Ozdal, Ö. G., Özdal, M., Algur, Ö. F., \& Sezen, A. (2016b). Isolation and identification of $\alpha$-Endosulfan degrading bacteria from insect microflora. Turkish Journal of Agriculture-Food Science and Technology, 4(4), 248-254.

Ozdal, M. (2019). A new strategy for the efficient production of pyocyanin, a versatile pigment, in Pseudomonas aeruginosa OG1 via toluene addition. 3 Biotech, $9(10), 374$.

Ozdal, M., Ozdal, O. G., Algur, O. F., \& Kurbanoglu, E. B. (2017). Biodegradation of $\alpha$-endosulfan via hydrolysis pathway by Stenotrophomonas maltophilia OG2. 3 Biotech, 7(2), 113.

Pietri, J. E., \& Liang, D. (2018). The Links Between Insect Symbionts and Insecticide Resistance: Causal Relationships and Physiological Tradeoffs. Annals of the Entomological Society of America, 111(3), 92-97.

Pietri, J. E., Tiffany, C., \& Liang, D. (2018). Disruption of the microbiota affects physiological and evolutionary aspects of insecticide resistance in the German cockroach, an important urban pest. PloS One, 13(12), e0207985.

Pourbabaee, A. A., Soleymani, S., Farahbakhsh, M., \& Torabi, E. (2018). Biodegradation of diazinon by the Stenotrophomonas maltophilia PS: pesticide dissipation kinetics and breakdown characterization using FTIR. International Journal of Environmental Science and Technology, 15(5), 1073-1084.

Ramakrishnan, B., Venkateswarlu, K., Sethunathan, N., \& Megharaj, M. (2019). Local applications but global implications: Can pesticides drive microorganisms to develop antimicrobial resistance? Science of The Total Environment, 654, 177-189.

Ramu, S., \& Seetharaman, B. (2014). Biodegradation of acephate and methamidophos by a soil bacterium Pseudomonas aeruginosa strain Is-6. Journal of Environmental Science and Health, Part B, 49(1), 23-34.

Song, H., Zhou, Z., Liu, Y., Deng, S., \& Xu, H. (2015). Kinetics and mechanism of fenpropathrin biodegradation by a newly isolated Pseudomonas aeruginosa sp. strain JQ-41. Current Microbiology, 71(3), 326-332.

Tang, J., Liu, B., Shi, Y., Zeng, C. Y., Chen, T. T., Zeng, L., \& Zhang, Q. (2018). Isolation, identification, and fenvalerate-degrading potential of Bacillus licheniformis CY-012. Biotechnology \& Biotechnological Equipment, 32(3), 574-582.

Xia, X., Zheng, D., Zhong, H., Qin, B., Gurr, G. M., Vasseur, L., Lin H., Bai J., He, W., \& You, M. (2013). DNA sequencing reveals the midgut microbiota of diamondback moth, Cimex xylostella (L.) and a possible relationship with insecticide resistance. PLoS One. 8(7): e68852.

Yang, F., Jiang, Q., Zhu, M., Zhao, L., \& Zhang, Y. (2017). Effects of biochars and MWNTs on biodegradation behavior of atrazine by Acinetobacter lwoffii DNS32. Science of the Total Environment, 577, 54-60.

Zhan, H., Wang, H., Liao, L., Feng, Y., Fan, X., Zhang, L., \& Chen, S. (2018). Kinetics and novel degradation pathway of permethrin in Acinetobacter baumannii ZH-14. Frontiers in Microbiology, 9, 98.

Zhang, H., Zhang, Y., Hou, Z., Wang, X., Wang, J., Lu, Z., Zhao, X., Sun, F., \& Pan, H. (2016). Biodegradation potential of deltamethrin by the Bacillus cereus strain Y1 in both culture and contaminated soil. International Biodeterioration \& Biodegradation, 106, 53-59.

Zhao, J., Chi, Y., Liu, F., Jia, D., \& Yao, K. (2015). Effects of two surfactants and beta-cyclodextrin on beta-cypermethrin degradation by Bacillus licheniformis B-1. Journal of Agricultural and Food Chemistry, 63(50), 10729-10735. 